\title{
原発事故被災長期避難住民の 暮らしをどう再建するか
}

\section{被災住民の地位を安定させるための提言に向けて}

東日本大震災から早くも6年が経過した。しかし、それに伴う福島第一原発事故がもたらした問 題はあまりに大きく、その多くは未解決である。そのひとつは、原発事故の結果として元の居住 地から意に反して避難することを余儀なくされた、今なお 12 万人を超える人びとの問題である。

2015年6月、政府は、2017年3月をめどに避難指示解除準備区域亡居住制限区域の避難指示を 解除する方針を決定した。その後、順次解除が進められている。それによって避難者の元の自治 体への帰還を促進し、復興を眼に見える形にしようとしているのである。

しかし、避難指示が解除されることと、対象住民が実際に帰還するかどうかは別のことがらで ある。実際、これまでの例では、解除後ただちに帰還した人の人数は極めて限られている。一方、 避難指示の解除は、避難者に対するさまざまな支援や損害賠償の打ち切りと結びつけられようと している。避難者の多くは、引き続き困難な状況のもとに置かれているのである。

日本学術会議は、これまでに公表したいくつかの提言において、福島第一原発事故の結果とし て避難することを余儀なくされた被災住民について、避難元への帰還か移住かの二者択一を迫る のではなく、被災住民の意向を尊重しつつ、より柔軟な政策をとるべきことを主張してきた。また、 その一環として、避難した被災住民が避難元自治体と避難先自治体の双方との結びつきを維持す る（その意味で「二重の地位」をもつ）ことを可能にする制度を設けることを提案してきた。

そこで、第23期においては、東日本大震災復興支援委員会「原子力発電所事故に伴う健康影響 評価と国民の健康管理並びに医療のあり方検討分科会」のもとに、「原子力発電所事故被災住民の 『二重の地位』を考える小委員会」を設置し、「二重の地位」についての具体的な制度を提案すべく、 審議を行っている。

このような制度を構想するためには、避難住民の現状についての深い理解が前提となる。そこで、 2016年9月17日に「原発事故被災長期避難住民の暮らしをどう再建するか」をテーマとする公開 シンポジウム（主催：原子力発電所事故に伴う健康影響評価と国民の健康管理並びに医療のあり 方検討分科会、社会学委員会「東日本大震災の被害·影響構造と日本社会の再生の道を探る分科会」 および帝京大学）を開催し、復興計画と帰還問題、原発事故被災者の健康問題、避難者のコ三ュ 二ティ問題、避難住民の「二重の地位」保障問題などについて意見交換を行った。本特集は、そ の記録である。

日本学術会議連携会員 原子力発電所事故被災住民の「二重の地位」を考える小委員会委員長 神奈川大学法学部教授 小森田秋夫 